Letter

\section{Dr. Trefond et al reply}

\section{To the Editor:}

We thank Conway et $\mathrm{al}^{1}$ for their comments on our article reporting a case of giant cell arteritis (GCA) after SARS-CoV-2 vaccination. ${ }^{2}$ We agree with Conway et $\mathrm{al}^{1}$ and also emphasize the interest in SARS-CoV-2 vaccination, which had a reassuring safety profile in a cohort of 1519 patients with rheumatic and musculoskeletal diseases. ${ }^{3}$

Indeed, the association between GCA and the SARS-CoV-2 vaccination could have been pure coincidence, but we know that there are trigger factors without being able to confirm if they are causal factors. This association has also been reported in antineutrophil cytoplasmic antibody-associated vasculitis ${ }^{4}$ and we agree that we need large epidemiological studies to ascertain the potential relationship.

In the title of our study, we emphasized the particular phenotype of this case, which was a low level of C-reactive protein (CRP). ${ }^{2}$ The random incidence of GCA in France estimated by Conway et $\mathrm{al}^{1}$ would be very different with low levels of CRP. In our cohort from 2004 to 2020 of 116 patients with positive temporal artery biopsy (TAB), we had 2 patients (1.7\%) with an initial CRP level $<10 \mathrm{mg} / \mathrm{L}$ and none $\leq 5 \mathrm{mg} / \mathrm{L}$ (unpublished data). The proportion was similar $(2 / 119,1.7 \%)$ in the cohort from Parikh et $\mathrm{al}^{5}$ in 2006.

Our message ${ }^{2}$ was addressed not to the general population but to clinicians so as to help in diagnosis. Patients may indeed pay more attention to their symptoms after vaccination since they are asked to do so, but some diagnoses can hide behind these symptoms, and we know the potential damage caused by GCA. Patient history should include vaccinations. Further, when the symptoms presented are compatible with GCA, a CRP level $\leq 5 \mathrm{mg} / \mathrm{L}$ should not rule out a GCA diagnosis and a TAB should be performed.
Ludovic Trefond ${ }^{1,2}(\mathbb{D}, \mathrm{MD}$

Agathe Sauret ${ }^{1}, \mathrm{MD}$

Julien Stievenart ${ }^{1}$ (D), MD

Louis Olagne ${ }^{1}, \mathrm{MD}$

Benedicte Guelon ${ }^{1}$, MD

Perrine Smets ${ }^{1}, \mathrm{MD}$

Olivier Aumaitrere ${ }^{1,2}, \mathrm{MD}, \mathrm{PhD}$

Marc André ${ }^{1,2}, \mathrm{MD}, \mathrm{PhD}$

${ }^{1} \mathrm{CHU}$ Clermont-Ferrand, Service de Médecine Interne, Hôpital Gabriel Montpied;

${ }^{2}$ Université Clermont Auvergne, Inserm U1071, INRA USC2018, M2iSH, Clermont-Ferrand, France.

The authors declare no conflicts of interest relevant to this article. Address correspondence to Dr. L. Trefond, Médecine Interne, CHU Gabriel Montpied, 58, rue Montalembert, 63000 Clermont-Ferrand, France.Email: ludovic.trefond@chu-clermontferrrand.fr.

\section{REFERENCES}

1. Conway R, Brouwer E, Geest KSM van der, et al. Dr. Conway et al reply. J Rheumatol 2021 Oct 1 (Epub ahead of print).

2. Sauret A, Stievenart J, Smets P, et al. Case of giant cell arteritis after SARS-CoV-2 vaccination: a particular phenotype? J Rheumatol 2021 Oct 1 (Epub ahead of print).

3. Machado PM, Lawson-Tovey S, Hyrich K, et al. Covid-19 vaccine safety in patients with rheumatic and musculoskeletal disease. Ann Rheum Dis 2021;80:199-200.

4. Villa M, Díaz-Crespo F, Pérez de José A, et al. A case of ANCA-associated vasculitis after AZD1222 (Oxford-AstraZeneca) SARS-CoV-2 vaccination: casualty or causality? Kidney Int 2021;100:937-8.

5. Parikh M, Miller NR, Lee AG, et al. Prevalence of a normal $\mathrm{C}$-reactive protein with an elevated erythrocyte sedimentation rate in biopsy-proven giant cell arteritis. Ophthalmology 2006; 113:1842-5. 


\section{Correction}

Dr. Trefond et al reply: Giant Cell Arteritis After SARS-CoV-2 Vaccination-Coincidence or Trigger?

Ludovic Trefond, Agathe Sauret, Julien Stievenart, Louis Olagne, Benedicte Guelon, Perrine Smets, Olivier Aumaître, and Marc André

J Rheumatol 2022; doi: 10.3899/jrheum.211158

The title of this article was updated from "Dr. Trefond et al reply" to "Dr. Trefond et al reply: Giant Cell Arteritis After SARS-CoV-2 Vaccination-Coincidence or Trigger?” to clarify that it is a second comment on the article, "Case of Giant Cell Arteritis After SARS-CoV-2 Vaccination: A Particular Phenotype?" and the subsequent comment, "Dr. Conway et al reply."

This correction applies only to the First Release published on March 1, 2022. The correct text appears in the print and online issues.

doi: 10.3899/jrheum.211158.C1 